\title{
MEASURING THE EFFICIENCY OF EU13 NUTS 2 REGIONS BASED ON RCI APPROACH
}

\section{M'řr ENÍ EFEKTIVITY REGIONš NUTS 2 ZEMÍ EU13 NA ZÁKLAD'n Př ÍSTUPU RCI}

\section{ING. MichaELA STANÍLKOVÁ}

\author{
Katedra evropské integrace $\mid$ Department of European Integration \\ Ekonomická fakulta Faculty of Economics \\ Vysoká ġkola báŔská - Technická univerzita Ostrava $\mid V \dot{B}$ ï Technical University of Ostrava \\ $\bowtie$ Sokolská tŚda 33, 70121 Ostrava, Czech Republic \\ E-mail: michaela.stanickova@vsb.cz
}

\begin{abstract}
Annotation
Paper deals with an application of Data Envelopment Analysis methods to multicriteria efficiency evaluation of NUTS 2 regions within ñnewò Member States joining the EU in 2004, 2007 and 2013. The main aim of the paper is to analyse a level of efficiency achieved in individual NUTS 2 regions of EU13. Empirical analysis is based on the competitiveness scores (input and output dimension) individually achieved by all evaluated regions within Regional Competitiveness Index 2013 approach. Using of DEA method in the form of efficiency and super efficiency model seems to be convenient because there is not only one factor evaluated, but a set of different factors that determine the level of regional competitiveness. DEA method is based on input and output indicators and evaluates the efficiency how regions are able to transform their inputs into outputs. Therefore, efficiency of each region is thus perceived like a source/mirror of competitiveness.
\end{abstract}

\section{Key words}

competitiveness, DEA method, NUTS 2 region, RCI, regional efficiency

\section{Anotace}

PŚsp円uek se zabývá aplikací metody analýzy obalu dat za úlelem vícekriteriálního hodnocení efektivity region \ NUTS 2 v rámci skupiny Ănovýchñ ḷ lenských stát T EU, jeǵpŚistoupily v letech 2004,

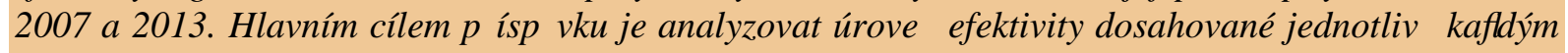
regionem NUTS 2 v rámci skupiny stát丁 EU13. Empirická analýza je zaloǵena na hodnotách skóre indexu konkurenceschopnosti (dimenze vstup a výstup) dosahované jednotlivými hodnocenými regiony v rámci konceptu Indexu regionální konkurenceschopnosti 2013. Vyuǵití metody DEA ve form modelu efektivity a super efektivity se jeví jako vhodné, jelikoǵnení hodnocen pouze jeden faktor, ale skupina rozlị̣ných faktorT ur|̣jících úroveŔ regionální konkurenceschopnosti. Metoda DEA je zaloǵena na indikátorech vstupu a výstupu a hodnotí efektivitu, sjakou jsou regiony schopny transformovat vstupy na výstupy. Z tohoto dTvodu je efektivita kaǵdého regionu povaǵsvána za zdroj/zrcadlo konkurenceschopnosti.

\section{Klí| ová slova}

konkurenceschopnost, metoda DEA, NUTS 2 region, RCI, regionální efektivita

JEL classification: C67, R11, R13

\section{Introduction}

The European Union (EU) is an economic and political partnership representing a unique form of cooperation among 28 Member States today. In the EU, the process of achieving an increasing level of 
competitiveness is significantly difficult by the heterogeneity of countries and regions in many areas. The EU countries are highly heterogeneous in their sectorial specialisations and performance. Although, the EU is one of the most developed parts of the world with high living standards, there exist significant and huge economic, social and territorial disparities having a negative impact on the balanced development across Member States and their regions, and thus weaken EUôs competitiveness in a global context (Poledníková, Lelková, 2012). The European integration process is thus guided by striving for two different objectives: to foster economic competitiveness and to reduce disparities (which were growing after EU enlargement history) (Molle, 2007). The EU has a long viewed enlargement process as an historic opportunity to further the integration of the continent by peaceful means and an extraordinary opportunity to promote political stability and economic prosperity in Europe. Since 2004, EU Membership has grown from 15 to 28 EU Member States, bringing in most states of Central and Eastern Europe and fulfilling an historic pledge to further the integration of the European continent by peaceful means. The carefully managed process of enlargement is one of the EUâs most powerful policy tools, and that, over the years, it has helped to transform many European states into functioning democracies, free market economies and more affluent countries. The EU maintains that the enlargement door remains open to any European country be able to fulfil the EUô political and economic criteria for Membership. At the same time, many observers assess that EU enlargement may soon be reaching its limits, both geographically and in terms of public enthusiasm for further expansion.

The gradual access of new Member States into the EU was associated with increased regional disparities (gaps) and a threat to the competitiveness and internal cohesion. Has increased integration within the EU and the rest of the world helped the EU as a whole to become a more globally competitive? Certainly, but different EU Member States, or groups of Member States have taken different approaches to this integration process. From this point of view, the main aim of the paper is to measure and evaluate the level of efficiency achieved by individual EU NUTS 2 regions within ñnewò EU Member States based on competitiveness scores of these regions within Regional Competitiveness Index (RCI) approach. Efficiency of each region is thus perceived like a mirror of competitiveness and the differences between regions within Central and Eastern Europe and Balkan Countries are the main orientation of this paper.

\section{Relations between competitiveness and efficiency}

The support of cohesion and balanced development together with increasing level of competitiveness belong to the temporary EUâ key development objectives. In the global economy regions are increasingly becoming the drivers of the economy and generally one of the most striking features of regional economies is the presence of clusters, or geographic concentrations of linked industries. Current economic fundamentals are threatened by the shifting of production activities to places with better conditions. The regional competitiveness is also affected by the regionalization of public policy because of the shifting of decision-making and coordination of activities at the regional level. Within governmental circles, interest has grown in the regional foundations of national competitiveness, and with developing new forms of regionally based policy interventions to help improve the competitiveness of every region and major city, and hence the national economy as a whole. Regions play an increasingly important role in the economic development of states. In relation to competitiveness, efficiency is complementary objective, which determines the long-term development of areas in a globalized economy. Therefore in recent years, the topics about measuring and evaluating of competitiveness and efficiency have enjoyed economic interest. Although there is no uniform definition and understanding of these terms, these multidimensional concepts remain ones of the basic standards of performance evaluation and it is also seen as a reflection of success of area in a wider comparison. Increasing competitiveness is generally considered to be the only sustainable way of improving living standards in the long-term period (Barrell, Mason, O Mahony, 2000).

Efficiency management is one of the major sources of sustainable national competitiveness. A systematic understanding of the factors that affect efficiency, and subsequently also competitiveness, is very important. Dynamic efficiency is also highly important for many economic subjects (e.g. 
companies, states and regions) as a whole and for the individuals involving in it. But it necessary to distinguish between efficiency and effectiveness. Efficiency and effectiveness analysis is based on the relationship between inputs (entries), outputs (results) and outcomes (effects). As it can be seen in Fig. 1 , the efficiency is given by the ratio of inputs to outputs, but there is difference between the technical efficiency and the allocative efficiency. The technical efficiency implies a relation between inputs and outputs on the frontier production curve, but not any form of technical efficiency makes sense in economic terms, and this deficiency is captured through the allocative efficiency that requires a cost/benefit ratio. The effectiveness implies a relationship between outputs and outcomes, thus effects of activities to the real economy and the essential conditions for national competitiveness.

Fig. 1: Relationship between efficiency and effectiveness

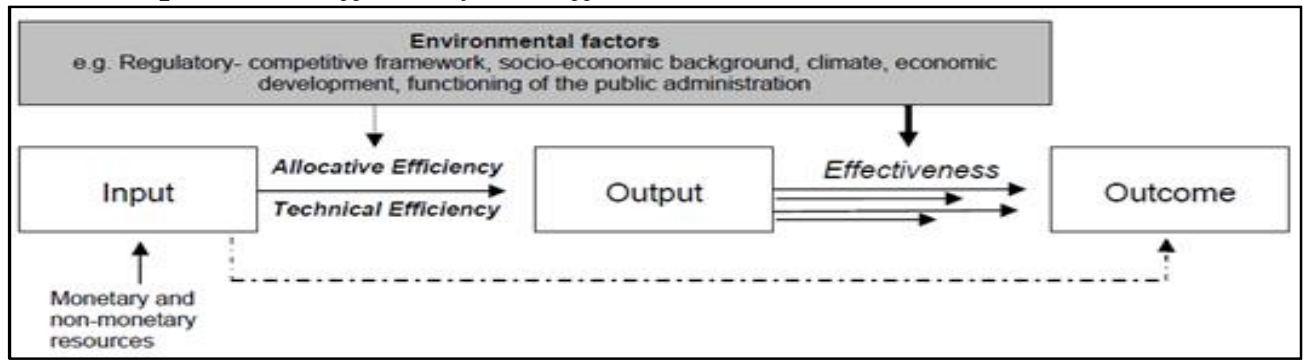

Source: Melecký, 2013

\section{Theoretical background of empirical analysis}

Measurement and evaluation of efficiency is an important issue for at least two reasons. First, in a group of units where only limited number of candidates can be selected, the efficiency of each must be evaluated in a fair and consistent manner. Second, as time progresses, better efficiency is expected. Hence, the units with declining efficiency must be identified in order to make the necessary improvements (Greenaway, Görg, Kneller, 2008). The efficiency of areas, in this case of regions, can be evaluated in either a cross-sectional or a time-series manner, and the Data Envelopment Analysis (DEA) is a useful empirical method for both types of efficiency evaluation. DEA is a relatively new òdata orientedò approach for providing a relative efficiency assessment and evaluating the efficiency of a set of peer entities called Decision Making Units (DMUs) which convert multiple inputs into multiple outputs. DEA is thus a multi-criteria decision making method for evaluating efficiency and productivity of a homogenous group (DMUs). The aim of DEA method is to examine DMU if they are efficient or not efficient by the size and quantity of consumed resources by the produced outputs. In DEA approach, DMUs usually use a set of resources as inputs and transform them into a set of outcomes as outputs. The efficiency score of DMUs in the presence of multiple input and output factors is defined as follows (1):

$$
\text { Efficiency of } D M U=\frac{\text { weighted sum of outputs }}{\text { weighted sum of inputs }} \text {. }
$$

In recent years, we have seen a great variety of applications of DEA for evaluating the performances of many different kinds of entities engaged in many different activities. Because of low assumption requirements DEA has also opened up possibilities for use in cases which have been resistant to other approaches because of the complex (often unknown) nature of relations between multiple inputs and multiple outputs involved in DMUs. DEA method is a convenient method for comparing regional efficiency as an assumption for performance of territory because DEA does not evaluate only one factor, but a set of different factors that determine degree of economic development (Melecký, 2013).

Efficiency analysis starts from building database of indicators that are part of RCI 2013 approach. RCI covers a wide range of issues related to territorial competitiveness including innovation, quality of institutions, infrastructure (including digital networks) and measures of health and human capital. RCI may serve as a tool to assist EU regions in setting the right priorities to further increase their 
competitiveness. Because of this reason, eleven pillars of RCI are grouped according to the different dimensions (input versus output aspects) of regional competitiveness they describe. The terms ónputsô and óutputsôare meant to classify pillars into those which describe driving forces of competitiveness, also in terms of long-term potentiality, and those which are direct or indirect outcomes of a competitive society and economy (Annoni, Kozovska, 2010). Methodology of RCI is thus suitable for measuring regional efficiency by DEA method. In this paper, as input indicators to DEA are not used the initial RCI 2013 indicators (73 indicators entered RCI 2013 having passed the statistical tests), but competitiveness scores of RCI 2013 pillars which are available at regional level. RCI 2013 scores are adjusted to positive values through Factor analysis, since DEA does not allow negative values of the input variables. In Appendix 1, input pillars and output pillars are specified $\ddot{i}$ these are used in the paper.

Analysis is applied to regional territory of ñnewò EU Member States, i.e. 13 countries joined to the EU in 2004, 2007 and 2013. These 13 countries cover in total 57 NUTS 2 regions ${ }^{1} \ddot{i}$ Bulgaria 6 (BG), Cyprus 1 (CY), Czech Republic 7 (CZ), Estonia 1 (EE), Croatia 2 (CR), Hungary 7 (HU), Lithuania 1 (LT), Latvia 1 (LV), Malta 1 (MT), Poland 16 (PL), Romania 8 (RO), Slovenia 2 (SI) and Slovakia 4 (SK). Why was this group of regions chosen for empirical analysis? Where the impact of enlargement is seen perhaps most clearly is in the developments in intra-EU trade and, particularly, in trade in intermediate goods. The EU13 Member States have become important suppliers of intermediate goods to several key EU producers (Annoni, Dijkstra, 2013). Their inputs are therefore increasingly vital to the competitiveness of final goods exports from other EU countries. In addition, EU13 countries are themselves expanding their sourcing of intermediate goods abroad, both within the Union and globally. Thus on the one hand EU13 companies are becoming more important sources for industries in other EU countries, while they themselves are becoming more globalised, taking advantage of greater openness both within the EU and towards the rest of the world to better integrate their production structure. On the other hand, ñnewò EU Member States have to scope with conditions of Single internal market and rules of EU policies, what is in some areas problematic because of their historical heritage of mark ñCountries behind Iron Curtainò So, the main question is, what is the current position of individual regions within the group of Central, Eastern and Balkan European countries? Do all of these regions have the same position and conditions for competing with ñoldòEU Member States?

Empirical analysis is based on a frontier non-parametric approach and aims to study efficiency and trend of returns to scale (RTS). This is based on model introduced by A. Charnes, W.W. Cooper and E. Rhodes in 1978, i.e. CCR model assuming constant returns to scale (CRS). In this paper, it's used input orientation of this model, because the attention is paid to endogenous factors of regional competitiveness. According to the chosen model and the relationship between number of DMU and number of inputs and outputs, the number of efficient units can be relatively large. Because there were many efficient regions in the classification, in the paper is also designed a model of super efficiency. The way in which DEA program computes efficiency scores can be explained briefly using mathematical notation in model (2) (Cook and Seiford, 2009):

\section{subject to}

$$
\left.\min \mathbf{z}=\theta_{\mathbf{q}^{-}} \stackrel{\cup}{\mathrm{O}}^{\mathrm{T}} \mathbf{e}^{\mathrm{T}} \mathbf{s}^{+}+\mathbf{e}^{\mathrm{T}} \mathbf{s}^{-}\right),
$$

$$
\begin{gathered}
\mathbf{X} \lambda+\mathbf{s}^{-}=\theta_{\mathbf{q}} \mathbf{x}_{\mathbf{q}}, \\
\mathbf{Y} \lambda-\mathbf{s}^{+}=\mathbf{y}_{\mathbf{q}}, \\
\lambda, \mathbf{s}^{+}, \mathbf{s}^{-} \geq 0,
\end{gathered}
$$

where $\mathrm{z}$ is the coefficient of efficiency of unit $\mathrm{U}_{\mathrm{q}} ; \theta_{\mathrm{q}}$ is radial variable indicates required rate of decrease of intput; Uis infinitesimal constant; $\mathrm{e}^{\mathrm{T}} \mathrm{\partial ris}^{\mathrm{i}}$ convexity condition, in the case of CRS: $\mathrm{e}^{\mathrm{T}}=(1$,

\footnotetext{
${ }^{1}$ In RCI 2013, capital regions are merged with one or more of their neighbouring regions: Wien (AT), Brussels (BE), Prague (CZ), Berlin (DE), Amsterdam (NL) and London (UK). The remaining NUTS 2 regions may contain multiple functional urban areas, but they do break up a single functional urban area in to distinct parts.
} 
1 , é, 1$) ; \mathrm{s}^{+}$, and $\mathrm{s}^{\bar{\top}}$ are vectors of slack variables for inputs and outputs; جrepresent vector of weights assigned to individual units; $x_{q}$ means vector of input of unit $\mathrm{U}_{\mathrm{q}} ; \mathrm{y}_{\mathrm{q}}$ means vector of output of unit $\mathrm{U}_{\mathrm{q}}$; $\mathrm{X}$ is input matrix; $\mathrm{Y}$ is output matrix. In CCR model aimed at inputs the efficiency coefficient of efficient DMU equals 1, but the efficiency coefficient of inefficient DMU is lower than 1.

In CCR model, efficiency coefficients of efficient units equal to 1. Depending on chosen model, but also on the relationship between number of units and number of inputs and outputs, number of efficient units can be relatively large. Due to the possibility of efficient units' classification, it is used Andersen-Petersen's model (APM) of super efficiency. Following constant return to scale (CRS) model is input oriented dual version of APM (3) (Andersen and Petersen, 1993):

\section{subject to}

$$
\min \theta_{\mathbf{q}}
$$

$$
\begin{gathered}
\sum_{\substack{\mathbf{j}=1 \\
\mathbf{j} \neq \mathbf{k}}}^{\mathrm{n}} \mathbf{x}_{\mathbf{i j}} \lambda_{\mathbf{j}}+\mathbf{s}_{\mathbf{i}}^{-}=\theta_{\mathbf{q}} \mathbf{x}_{\mathrm{iq}} ; \mathbf{i}=1,2, \ldots, \mathbf{m} \\
\sum_{\substack{\mathbf{j}=1 \\
\mathbf{j} \neq \mathbf{k}}}^{\mathrm{n}} \mathbf{y}_{\mathrm{ij}} \lambda_{\mathbf{j}}-\mathbf{s}_{\mathbf{i}}^{+}=\mathbf{y}_{\mathrm{iq}} ; \mathbf{i}=1,2, \ldots, \mathrm{r} \\
\lambda_{\mathbf{j}}, \mathbf{s}_{\mathbf{i}}^{+}, \mathbf{s}_{\mathbf{i}}^{-} \geq 0, \lambda_{\mathbf{q}}=0 \\
j=1,2, \ldots, n .
\end{gathered}
$$

where $x_{i q}$ and $y_{i q}$ are $i-t h$ inputs and i-th outputs of $\mathrm{DMU}_{\mathrm{q}} ; \theta_{\mathrm{q}}$ is efficiency index (intensity factor) of observed $\mathrm{DMU}_{\mathrm{q}}$; $z_{\mathrm{j}}$ is dual weight which show $\mathrm{DMU}_{\mathrm{j}}$ significance in definition of input-output mix of hypothetical composite unit, $\mathrm{DMU}_{\mathrm{q}}$ directly comparing with. The rate of efficiency of inefficient units $\left(\theta_{\mathrm{q}}<1\right)$ is identical to model (1); for units identified as efficient in model (2), provides IO APM (2) the rate of super efficiency higher than 1, i.e. $\theta_{\mathrm{q}}$ Oे 1 .

For solution of DEA method software tool based on solving linear programming problems is used in the paper ï Solver in MS Excel 2010, such as the DEA Frontier 2011.

\section{Application of DEA for efficiency evaluation of EU13 NUTS 2 regions}

The aim of DEA method is to examine DMU if they are efficient or inefficient by the size and quantity consumed resources by the produced outputs. The overall evaluation of efficiency of EU13 NUTS 2 regions is presented in Tab. 1, which shows levels of regional efficiency in IO CCR model and position of each region based on IO APM model of super efficiency (because of classification of all evaluated DMU). In Tab. 1, all evaluated NUTS 2 regions and their efficiency coefficients in IO APM CRS model of super efficiency are coloured by shadows of grey colour. Regions belonging to the group of the most efficient region are marked by dark grey colour and placed at front $20^{\text {th }}$ positions $i$ these regions achieved level of efficiency coefficients at 1.0 in IO CCR CRS model (marked by bold font in Tab. 1). The group of the most efficient regions is followed by the group of slight efficient regions. Some NUTS 2 regions of all EU13 countries are included in this group. These regions achieved level of efficiency coefficients lower than 1.0 and higher than 0.9 points and are placed from $21^{\text {st }}$ to $49^{\text {th }}$ position. Last DMUs belong to the group of inefficient NUTS 2 regions $\ddot{i}$ this group is covered by Bulgarian, Czech, Hungarian and Polish NUTS 2 regions. Level of efficiency coefficients is lower than 0.9 in the case of inefficient regions and they are placed from $50^{\text {th }}$ to $57^{\text {th }}$ position $\ddot{i}$ it's marked by italic font.

The best results achieved Romanian and Bulgarian regions. Generally, these regions belong to regions with average or lower/the lowest level of efficiency. In the paper are thus detected anomalies in the final classification of some NUTS 2 regions based on values of efficiency coefficients in IO APM CRS model of super efficiency. DEA method evaluates the volume of inputs for given outputs, which in case of some Bulgarian, Hungarian and Romanian regions seems to be more efficient than others, although these regions generally belong to the less or average developed regions within the whole EU. 
This fact could be a prerequisite for further research on evaluation of regional efficiency by other advanced DEA models, e.g. in $1^{\text {st }}$ phase to divide evaluated regions into groups-levels according to all efficient frontiers via Context-Dependent DEA approach. By this stratification, into efficiency analysis will enter more homogenous groups of regions, which will be evaluated separately according to closer features.

In Tab. 1, trend of returns to scale (RTS) of each region is also presented ï constant, increasing or decreasing. This trend is calculated based on comparison results of efficiency within RTS orientation ï constant (CRS) and variable (VRS).

Tab. 1: DEA efficiency within EU 13 NUTS 2 regions

\begin{tabular}{|c|c|c|c|c|c|c|c|c|}
\hline \multirow{2}{*}{ DMU } & \multirow{2}{*}{$\begin{array}{c}\text { Efficiency } \\
\text { IO CCR CRS }\end{array}$} & \multirow{2}{*}{$\begin{array}{c}\text { Super Efficiency } \\
\text { IO APM CRS }\end{array}$} & \multicolumn{4}{|c|}{ RTS } & \multicolumn{2}{|c|}{ Final Rank ï IO APM CRS } \\
\hline & & & IO VRS & IO CRS & $\Sigma \lambda$ & IO RTS & NUTS 2 Region & Rank \\
\hline BG31 & 1.00000 & 1.07073 & 1.00000 & 1.00000 & 1.00000 & Constant & $\mathrm{RO} 32-2.23004$ & 1 \\
\hline BG32 & 0.87966 & 0.87966 & 1.00000 & 0.87966 & 0.76108 & Increasing & BG41 - 1.25227 & 2 \\
\hline BG33 & 1.00000 & 1.01302 & 1.00000 & 1.00000 & 1.00000 & Constant & HU32 - 1.24526 & 3 \\
\hline BG34 & 1.00000 & 1.16981 & 1.00000 & 1.00000 & 1.00000 & Constant & MT00 - 1.23443 & 4 \\
\hline BG41 & 1.00000 & 1.25227 & 1.00000 & 1.00000 & 1.00000 & Constant & BG34 - 1.16981 & 5 \\
\hline BG42 & 0.89150 & 0.89150 & 0.95518 & 0.89150 & 0.86427 & Increasing & $\mathrm{RO} 21-1.16067$ & 6 \\
\hline CY00 & 1.00000 & 1.05866 & 1.00000 & 1.00000 & 1.00000 & Constant & EE00 - 1.09747 & 7 \\
\hline $\mathrm{CZO0}$ & 0.90111 & 0.90111 & 0.91930 & 0.90111 & 1.03334 & Decreasing & $\mathrm{RO} 42-1.09301$ & 8 \\
\hline $\mathrm{CZO3}$ & 0.85648 & 0.85648 & 0.87117 & 0.85648 & 0.94799 & Increasing & R031 - 1.09024 & 9 \\
\hline CZ04 & 0.88021 & 0.88021 & 0.88098 & 0.88021 & 1.00177 & Decreasing & HU10 - 1.08781 & 10 \\
\hline $\mathrm{CZ} 05$ & 0.88682 & 0.88682 & 0.90605 & 0.88682 & 0.92214 & Increasing & HR04 - 1.08023 & 11 \\
\hline CZ06 & 0.88903 & 0.88903 & 0.89109 & 0.88903 & 1.01165 & Decreasing & R011 - 1.07814 & 12 \\
\hline CZ07 & 0.95769 & 0.95769 & 0.97279 & 0.95769 & 0.94224 & Increasing & BG31 - 1.07073 & 13 \\
\hline CZ08 & 0.97881 & 0.97881 & 0.99080 & 0.97881 & 0.93720 & Increasing & CY00 - 1.05866 & 14 \\
\hline EE00 & 1.00000 & 1.09747 & 1.00000 & 1.00000 & 1.00000 & Constant & HU23 - 1.05087 & 15 \\
\hline HR03 & 0.98401 & 0.98401 & 1.00000 & 0.98401 & 0.91388 & Increasing & R041 - 1.01797 & 16 \\
\hline HR04 & 1.00000 & 1.08023 & 1.00000 & 1.00000 & 1.00000 & Constant & BG33 - 1.01302 & 17 \\
\hline HU10 & 1.00000 & 1.08781 & 1.00000 & 1.00000 & 1.00000 & Constant & PL22 - 1.00993 & 18 \\
\hline HU21 & 0.94373 & 0.94373 & 0.97757 & 0.94373 & 1.04489 & Decreasing & SI02 - 1.00930 & 19 \\
\hline HU22 & 0.88275 & 0.88275 & 0.91720 & 0.88275 & 1.03013 & Decreasing & $\mathrm{RO} 22-1.00708$ & 20 \\
\hline HU23 & 1.00000 & 1.05087 & 1.00000 & 1.00000 & 1.00000 & Constant & HU31 - 0.99916 & 21 \\
\hline HU31 & 0.99916 & 0.99916 & 0.99923 & 0.99916 & 1.01776 & Decreasing & HR03 - 0.98401 & 22 \\
\hline HU32 & 1.00000 & 1.24526 & 1.00000 & 1.00000 & 1.00000 & Constant & SK01 - 0.98217 & 23 \\
\hline HU33 & 0.97979 & 0.97979 & 0.98969 & 0.97979 & 1.01273 & Decreasing & SK03 - 0.98057 & 24 \\
\hline LT00 & 0.93862 & 0.93862 & 0.98744 & 0.93862 & 0.90384 & Increasing & HU33 - 0.97979 & 25 \\
\hline LV00 & 0.92565 & 0.92565 & 0.98565 & 0.92565 & 0.84348 & Increasing & CZ08 - 0.97881 & 26 \\
\hline MT00 & 1.00000 & 1.23443 & 1.00000 & 1.00000 & 1.00000 & Constant & PL11 - 0.97807 & 27 \\
\hline PL11 & 0.97807 & 0.97807 & 0.98181 & 0.97807 & 0.98320 & Increasing & PL41 - 0.96692 & 28 \\
\hline PL12 & 0.95736 & 0.95736 & 0.96079 & 0.95736 & 1.00598 & Decreasing & PL21 - 0.96049 & 29 \\
\hline PL21 & 0.96049 & 0.96049 & 0.96289 & 0.96049 & 0.99119 & Increasing & CZ07 - 0.95769 & 30 \\
\hline PL22 & 1.00000 & 1.00993 & 1.00000 & 1.00000 & 1.00000 & Constant & PL12 - 0.95736 & 31 \\
\hline PL31 & 0.93838 & 0.93838 & 0.99568 & 0.93838 & 0.86238 & Increasing & PL34 - 0.95443 & 32 \\
\hline PL32 & 0.90691 & 0.90691 & 0.98839 & 0.90691 & 0.80465 & Increasing & PL33 - 0.95045 & 33 \\
\hline PL33 & 0.95045 & 0.95045 & 1.00000 & 0.95045 & 0.81898 & Increasing & PL52 - 0.94861 & 34 \\
\hline PL34 & 0.95443 & 0.95443 & 1.00000 & 0.95443 & 0.88770 & Increasing & PL51 - 0.94732 & 35 \\
\hline PL41 & 0.96692 & 0.96692 & 0.96870 & 0.96692 & 0.99219 & Increasing & SK04 - 0.94546 & 36 \\
\hline PL42 & 0.88443 & 0.88443 & 0.91650 & 0.88443 & 0.91517 & Increasing & HU21 - 0.94373 & 37 \\
\hline PL43 & 0.92325 & 0.92325 & 0.92444 & 0.92325 & 0.99473 & Increasing & RO12 - 0.94341 & 38 \\
\hline PL51 & 0.94732 & 0.94732 & 0.96734 & 0.94732 & 0.92956 & Increasing & LT00 - 0.93862 & 39 \\
\hline PL52 & 0.94861 & 0.94861 & 0.95252 & 0.94861 & 0.98436 & Increasing & PL31 - 0.93838 & 40 \\
\hline PL61 & 0.93391 & 0.93391 & 0.97649 & 0.93391 & 0.86321 & Increasing & PL61 - 0.93391 & 41 \\
\hline PL62 & 0.92978 & 0.92978 & 0.98449 & 0.92978 & 0.87324 & Increasing & PL62 - 0.92978 & 42 \\
\hline PL63 & 0.91905 & 0.91905 & 0.96617 & 0.91905 & 0.87209 & Increasing & LV00 - 0.92565 & 43 \\
\hline $\mathrm{RO} 11$ & 1.00000 & 1.07814 & 1.00000 & 1.00000 & 1.00000 & Constant & PL43 - 0.92325 & 44 \\
\hline RO12 & 0.94341 & 0.94341 & 0.98088 & 0.94341 & 0.88172 & Increasing & SI01 - 0.92109 & 45 \\
\hline $\mathrm{RO} 21$ & 1.00000 & 1.16067 & 1.00000 & 1.00000 & 1.00000 & Constant & PL63 - 0.91905 & 46 \\
\hline $\mathrm{RO} 22$ & 1.00000 & 1.00708 & 1.00000 & 1.00000 & 1.00000 & Constant & SK02 - 0.91105 & 47 \\
\hline RO31 & 1.00000 & 1.09024 & 1.00000 & 1.00000 & 1.00000 & Constant & PL32 - 0.90691 & 48 \\
\hline
\end{tabular}




\begin{tabular}{|c|c|c|c|c|c|c|c|c|}
\hline \multirow{2}{*}{ DMU } & Efficiency & Super Efficiency & \multicolumn{4}{|c|}{ RTS } & \multicolumn{2}{|c|}{ Final Rank ï IO APM CRS } \\
\hline & IO CCR CRS & IO APM CRS & IO VRS & IO CRS & $\Sigma \lambda$ & IO RTS & NUTS 2 Region & Rank \\
\hline RO32 & 1.00000 & 2.23004 & 1.00000 & 1.00000 & 1.00000 & Constant & CZ00-0.90111 & 49 \\
\hline RO41 & & & 1.00000 & 1.00000 & 1.00000 & Constant & $B G 42-0.89150$ & 50 \\
\hline $\mathrm{RO} 42$ & 0000 & 1.09301 & 1.00000 & 1.00000 & 1.00000 & Constant & CZ06-0.88903 & 51 \\
\hline SI01 & 0.92109 & 0.92109 & 0.94875 & 0.92109 & 0.92251 & Increasing & CZ05- 0.88682 & 52 \\
\hline SI02 & & & & & & & $P L 42-0.88443$ & 53 \\
\hline SK01 & 98217 & 0.98217 & 1.00000 & 0.98217 & 1.19833 & Decreasing & $H U 22-0.88275$ & 54 \\
\hline SK02 & 91105 & 0.91105 & 0.91217 & 0.91105 & 0.99297 & Increasing & CZ04-0.88021 & 55 \\
\hline SK03 & & & 1.00000 & 0.98057 & 0.87488 & Increasing & $B G 32-0.87966$ & 56 \\
\hline SK04 & 0.94546 & 0.94546 & 0.99651 & 0.94546 & 0.86778 & Increasing & CZ03-0.85648 & 57 \\
\hline
\end{tabular}

Source: own calculation and elaboration, 2014

In following Fig. 1 it's possible to see evidential differences of efficiency IO CCR CRS model among 57 NUTS 2 regions. The line at 1.0 represents the efficient frontier $\ddot{i}$ at this level, DMU ratio of consumed inputs and produced outputs is in optimum. Distance of all evaluated regions from the efficient frontier is presented at Fig. 1, the most efficient regions are ranged at efficient line 1.0, inefficient regions are ranged below the efficient frontier; greater distance means lower efficiency.

\section{Fig. 1: Efficient frontier of EU 13 NUTS 2 regions based on IO CCR CRS model}

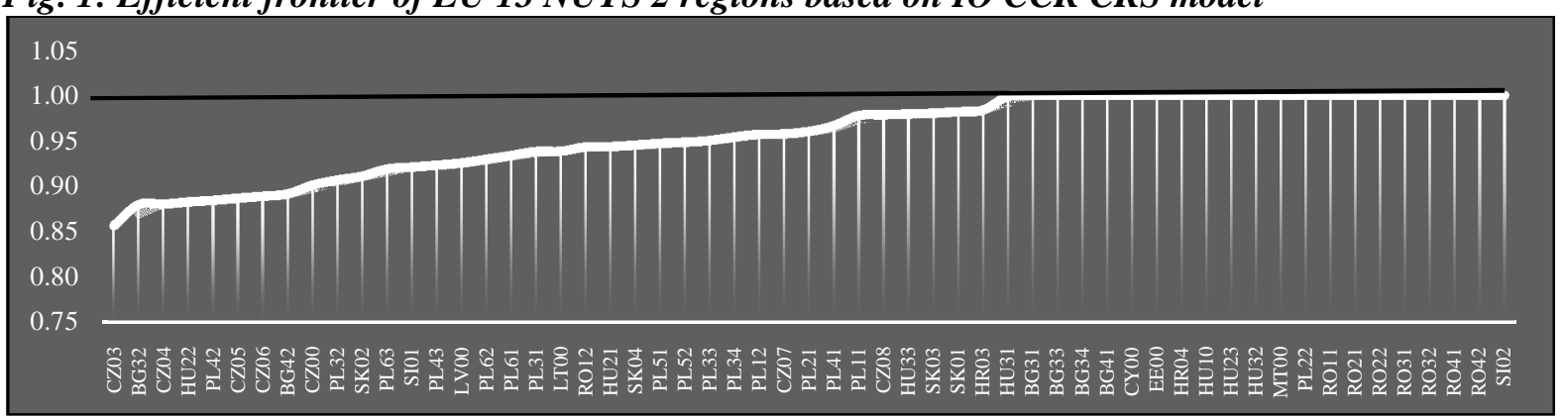

Source: own calculation and elaboration, 2014

\section{Conclusion}

The EUâ enlargement has helped the EU to maintain a strong performance, in spite of increased global competition. Challenges certainly remain, but its recent performance gives reason to believe that the EU can leverage its strengths even as the economic environment toughens. Regions have indeed to pick priorities for their development strategies. The economic crisis made this even more difficult as public funding becomes scarcer. This approach, evaluation competitive advantages/disadvantages by DEA efficiency analysis can provide a guide to what each region should focus on taking into account its specific situation, its overall level of development and level of efficiency of using inputs (internal factor endowment) to produced outputs (direct/indirect outcomes) which are able to withstand competition.

\section{References}

[1] ANDERSEN, P., PETERSEN, N.C., (1993). A Procedure for Ranking Efficient Units in Data Envelopment Analysis. Management Science, vol. 39, iss. 10, pp. 1261-1264. ISSN 0025-1909. DOI 10.1287/mnsc.39.10.1261.

[2] ANNONI, P., DIJKSTRA, L., (2013). EU Regional Competitiveness Index 2013. Luxembourg: Publication Office of the European Union. ISBN 978-92-79-32370-6.

[3] ANNONI, P., KOZOVSKA, K., (2010). EU Regional Competitiveness Index 2010. Luxembourg: Publication Office of the European Union. ISBN 978-92-79-15693-9.

[4] BARRELL, R., MASON, G., O’MAHONY, M., (2000). Productivity. Innovation and Economic Growth. Cambridge: Cambridge University Press. ISBN 978-0521780315.

[5] COOK, W.D., SEIFORD, L.M., (2009). Data envelopment analysis (DEA) ï Thirty years on. European Journal of Operation Research, vol. 192, iss. 1, pp. 1-17. ISSN 0377-2217. DOI 10.1016/j.ejor.2008.01.032. 
[6] GREENAWAY, D., GÖRG, H., KNELLER, R., (2008). Globalization and Productivity. Cheltenham: Edward Elgar Publishing Limited. ISBN 978-1845423803.

[7] MELECKÝ, L., (2013). Comparing of EU15 and EU12 Countries Efficiency by Application of DEA Approach. In 31st International Conference Mathematical Methods in Economics. Jihlava: College of Polytechnics Jihlava. p. 618-623. ISBN 978-80-87035-76-4.

[8] MOLLE, W., (2007). European Cohesion Policy. London: Routledge. ISBN 978-0415438124.

[9] POLEDNÍKOVÁ, E., LELKOVÁ, P., (2012). Evaluation of Regional Disparities in Visegrad Four Countries. Germany and Austria using the Cluster Analysis. In 15th International Colloquium on Regional Sciences. Conference Proceedings. Brno: Masarykova univerzita. pp. 36-47. ISBN 978-80-210-5875-0.

This paper was created under SGS project (SP2014/111) of Faculty of Economics. VǴB-Technical University of Ostrava and Operational Programme Education for Competitiveness ï Project CZ.1.07/2.3.00/20.0296.

\begin{tabular}{|c|c|c|c|c|c|c|c|c|c|}
\hline \multirow{2}{*}{$\begin{array}{c}\text { DMU } \\
\text { NUTS } 2 \\
\text { regions }\end{array}$} & \multicolumn{5}{|c|}{ INPUTS } & \multicolumn{4}{|c|}{ OUTPUTS } \\
\hline & $\mathrm{I}^{1}$ & $\mathrm{I}^{2}$ & $\mathrm{I}^{3}$ & $\mathrm{I}^{4}$ & $I^{5}$ & $\mathrm{O}^{1}$ & $\mathrm{O}^{2}$ & $\mathrm{O}^{3}$ & $\mathrm{O}^{4}$ \\
\hline BG31 & 1.65 & 2.80 & 2.16 & 2.14 & 2.04 & 2.96 & 2.45 & 2.67 & 2.63 \\
\hline BG32 & 1.91 & 2.79 & 2.24 & 2.92 & 2.23 & 3.07 & 2.58 & 2.60 & 2.82 \\
\hline BG33 & 2.89 & 2.85 & 1.90 & 2.88 & 2.02 & 2.97 & 2.45 & 3.10 & 2.88 \\
\hline BG34 & 1.95 & 2.81 & 1.42 & 2.59 & 2.11 & 3.24 & 2.43 & 2.64 & 2.54 \\
\hline BG41 & 2.18 & 3.03 & 2.87 & 3.40 & 2.62 & 4.10 & 2.84 & 4.66 & 3.69 \\
\hline BG42 & 2.84 & 2.91 & 2.36 & 2.63 & 2.19 & 3.10 & 2.52 & 2.49 & 2.64 \\
\hline CY00 & 3.91 & 2.99 & 4.42 & 3.71 & 3.34 & 4.35 & 3.13 & 3.94 & 3.69 \\
\hline $\mathrm{CZO0}$ & 3.49 & 3.82 & 3.72 & 4.63 & 4.09 & 4.47 & 3.74 & 4.39 & 4.51 \\
\hline CZ03 & 3.92 & 3.51 & 3.33 & 3.89 & 3.92 & 4.10 & 3.18 & 2.77 & 3.39 \\
\hline CZ04 & 3.13 & 3.77 & 2.90 & 3.84 & 3.87 & 3.47 & 3.48 & 2.72 & 3.22 \\
\hline CZ05 & 3.90 & 3.43 & 3.59 & 3.95 & 4.06 & 3.98 & 3.33 & 2.70 & 3.43 \\
\hline CZ06 & 3.59 & 3.54 & 3.78 & 3.59 & 3.99 & 3.85 & 3.30 & 3.21 & 3.58 \\
\hline CZ07 & 3.57 & 3.20 & 3.44 & 3.55 & 3.82 & 3.85 & 3.33 & 2.71 & 3.25 \\
\hline CZ08 & 3.67 & 3.26 & 3.38 & 3.85 & 3.97 & 3.56 & 3.55 & 2.72 & 2.92 \\
\hline EE00 & 3.88 & 2.79 & 3.16 & 3.98 & 3.94 & 3.70 & 2.46 & 3.64 & 4.20 \\
\hline HR03 & 1.95 & 2.90 & 2.89 & 2.88 & 3.22 & 3.36 & 2.74 & 3.74 & 3.05 \\
\hline HR04 & 2.21 & 3.07 & 2.91 & 2.89 & 3.09 & 3.29 & 3.22 & 3.79 & 3.24 \\
\hline HU10 & 3.05 & 3.61 & 2.61 & 3.78 & 3.81 & 3.95 & 3.59 & 4.72 & 4.40 \\
\hline HU21 & 3.65 & 3.45 & 2.07 & 3.54 & 3.61 & 3.72 & 3.24 & 2.74 & 3.38 \\
\hline HU22 & 3.65 & 3.53 & 2.35 & 3.61 & 3.60 & 3.97 & 3.08 & 2.75 & 3.09 \\
\hline HU23 & 3.65 & 2.85 & 1.86 & 3.30 & 3.45 & 3.38 & 2.74 & 2.95 & 3.60 \\
\hline HU31 & 3.59 & 3.10 & 1.84 & 3.31 & 3.40 & 3.18 & 3.04 & 2.51 & 3.55 \\
\hline HU32 & 3.59 & 3.00 & 1.36 & 3.13 & 3.31 & 3.30 & 2.86 & 2.71 & 3.12 \\
\hline HU33 & 3.59 & 3.07 & 1.78 & 3.02 & 3.42 & 3.67 & 2.84 & 2.75 & 3.24 \\
\hline LT00 & 3.10 & 2.88 & 2.09 & 3.52 & 3.63 & 3.39 & 2.69 & 2.89 & 3.45 \\
\hline LV00 & 3.17 & 2.94 & 2.19 & 3.34 & 3.11 & 3.24 & 2.45 & 3.53 & 3.22 \\
\hline MT00 & 4.33 & 2.84 & 4.51 & 2.53 & 4.43 & 3.60 & 2.68 & 4.01 & 3.67 \\
\hline PL11 & 3.18 & 3.21 & 2.57 & 3.24 & 3.24 & 3.82 & 3.27 & 2.88 & 3.16 \\
\hline PL12 & 3.02 & 3.46 & 2.84 & 4.01 & 3.24 & 4.23 & 3.49 & 4.16 & 4.00 \\
\hline PL21 & 3.12 & 3.28 & 3.21 & 3.41 & 3.21 & 3.69 & 3.38 & 2.84 & 3.70 \\
\hline PL22 & 2.96 & 3.46 & 2.91 & 3.80 & 3.21 & 3.59 & 3.78 & 3.06 & 3.17 \\
\hline PL31 & 3.16 & 2.85 & 2.86 & 3.42 & 3.09 & 3.72 & 2.80 & 2.46 & 3.14 \\
\hline PL32 & 3.12 & 2.89 & 3.20 & 3.22 & 3.09 & 3.31 & 2.85 & 2.22 & 3.19 \\
\hline PL33 & 3.17 & 2.95 & 2.70 & 3.40 & 3.09 & 3.25 & 3.10 & 2.24 & 2.71 \\
\hline PL34 & 3.06 & 2.76 & 2.99 & 3.22 & 3.09 & 3.77 & 2.66 & 2.45 & 2.91 \\
\hline PL41 & 2.96 & 3.14 & 2.82 & 2.98 & 3.30 & 3.48 & 3.14 & 2.53 & 3.04 \\
\hline PL42 & 3.11 & 3.16 & 2.67 & 3.12 & 3.30 & 3.56 & 2.86 & 2.95 & 3.09 \\
\hline PL43 & 3.05 & 3.22 & 2.55 & 2.94 & 3.30 & 3.77 & 2.93 & 2.62 & 3.01 \\
\hline PL51 & 2.90 & 3.19 & 2.64 & 3.45 & 3.32 & 3.81 & 3.23 & 3.04 & 3.22 \\
\hline PL52 & 3.32 & 3.25 & 3.02 & 3.27 & 3.32 & 3.56 & 3.27 & 2.56 & 3.06 \\
\hline PL61 & 3.07 & 3.01 & 2.65 & 3.19 & 3.20 & 3.24 & 3.03 & 2.59 & 3.10 \\
\hline PL62 & 3.28 & 2.84 & 2.70 & 2.75 & 3.20 & 3.32 & 2.69 & 2.62 & 2.89 \\
\hline PL63 & 3.21 & 3.03 & 2.97 & 3.37 & 3.20 & 3.78 & 2.96 & 3.03 & 3.42 \\
\hline
\end{tabular}




\begin{tabular}{|c|c|c|c|c|c|c|c|c|c|}
\hline \multirow{2}{*}{$\begin{array}{l}\text { DMU } \\
\text { NUTS } 2 \\
\text { regions }\end{array}$} & \multicolumn{5}{|c|}{ INPUTS } & \multicolumn{4}{|c|}{ OUTPUTS } \\
\hline & $\mathrm{I}^{1}$ & $\mathrm{I}^{2}$ & $\mathrm{I}^{3}$ & $\mathrm{I}^{4}$ & $\mathrm{I}^{5}$ & $\mathrm{O}^{1}$ & $\mathrm{O}^{2}$ & $\mathrm{O}^{3}$ & $\mathrm{O}^{4}$ \\
\hline RO11 & 2.81 & 2.80 & 2.10 & 2.43 & 2.12 & 4.07 & 2.59 & 2.39 & 3.03 \\
\hline RO12 & 2.51 & 2.85 & 2.20 & 2.57 & 2.07 & 3.18 & 2.62 & 2.45 & 2.67 \\
\hline $\mathrm{RO} 21$ & 1.97 & 2.79 & 2.16 & 2.42 & 1.85 & 3.94 & 2.55 & 2.35 & 2.59 \\
\hline RO22 & 2.03 & 2.78 & 1.93 & 2.29 & 1.99 & 3.14 & 2.58 & 2.40 & 2.51 \\
\hline RO31 & 2.21 & 3.10 & 2.00 & 2.42 & 2.13 & 3.31 & 2.95 & 2.16 & 2.58 \\
\hline $\mathrm{RO} 32$ & 1.21 & 3.39 & 2.92 & 4.08 & 2.74 & 4.46 & 3.79 & 4.13 & 4.65 \\
\hline $\mathrm{RO} 41$ & 2.44 & 2.75 & 2.33 & 2.35 & 2.07 & 3.44 & 2.61 & 2.18 & 2.90 \\
\hline $\mathrm{RO} 42$ & 1.83 & 2.87 & 1.93 & 2.62 & 2.18 & 3.84 & 2.57 & 2.41 & 3.26 \\
\hline SI01 & 3.80 & 3.22 & 3.64 & 4.22 & 3.64 & 4.07 & 3.23 & 3.49 & 3.51 \\
\hline SI02 & 3.80 & 3.33 & 3.71 & 4.64 & 3.64 & 4.45 & 3.48 & 4.53 & 4.43 \\
\hline SK01 & 3.44 & 3.98 & 3.52 & 4.69 & 3.79 & 4.51 & 4.09 & 5.23 & 5.03 \\
\hline SK02 & 3.13 & 3.52 & 2.98 & 3.51 & 3.78 & 3.44 & 3.38 & 2.63 & 3.27 \\
\hline SK03 & 3.26 & 2.97 & 2.87 & 3.19 & 3.61 & 3.16 & 3.16 & 2.86 & 3.03 \\
\hline SK04 & 3.26 & 2.92 & 2.66 & 2.93 & 3.52 & 2.97 & 2.94 & 2.97 & 2.93 \\
\hline
\end{tabular}

$\mathrm{I}^{1}$ Institutions. $\mathrm{I}^{2}$ Infrastructure. $\mathrm{I}^{3}$ Health. $\mathrm{I}^{4}$ Higher Education and Lifelong Learning. $\mathrm{I}^{5}$ Technological Readiness. $\mathrm{O}^{1}$ Labour Market Efficiency. $\mathrm{O}^{2}$ Market Size. $\mathrm{O}^{3}$ Business Sophistication. $\mathrm{O}^{4}$ Innovation Source: own calculation and elaboration, 2014 